\title{
Frozen debris lobe morphology and movement: an overview of eight dynamic features, southern Brooks Range, Alaska
}

\author{
Margaret M. Darrow ${ }^{1}$, Nora L. Gyswyt ${ }^{1}$, Jocelyn M. Simpson ${ }^{1}$, Ronald P. Daanen ${ }^{2}$, and Trent D. Hubbard ${ }^{2}$ \\ ${ }^{1}$ Department of Mining and Geological Engineering, University of Alaska Fairbanks, Fairbanks, Alaska 99775, USA \\ ${ }^{2}$ Alaska Division of Geological \& Geophysical Surveys, Fairbanks, Alaska 99709, USA \\ Correspondence to: Margaret M. Darrow (mmdarrow@alaska.edu)
}

Received: 6 January 2016 - Published in The Cryosphere Discuss.: 9 February 2016

Revised: 8 April 2016 - Accepted: 26 April 2016 - Published: 12 May 2016

\begin{abstract}
Frozen debris lobes (FDLs) are elongated, lobate permafrost features that mostly move through shear in zones near their bases. We present a comprehensive overview of eight FDLs within the Dalton Highway corridor (southern Brooks Range, Alaska), including their catchment geology and rock strengths, lobe soil characteristics, surface movement measurements collected between 2012 and 2015, and analysis of historic and modern imagery from 1955 to 2014. Field mapping and rock strength data indicate that the metasedimentary and metavolcanic bedrock forming the majority of the lobe catchments has very low to medium strength and is heavily fractured, thus easily contributing to FDL formation. The eight investigated FDLs consist of platy rocks typical of their catchments, organic debris, and an ice-poor soil matrix; massive ice, however, is present within FDLs as infiltration ice, concentrated within cracks open to the surface. Exposure of infiltration ice in retrogressive thaw slumps (RTSs) and associated debris flows leads to increased movement and various stages of destabilization, resulting in morphological differences among the lobes. Analysis of historic imagery indicates that movement of the eight investigated FDLs has been asynchronous over the study period, and since 1955, there has been an overall increase in movement rates of the investigated FDLs. The formation of surface features, such as cracks, scarps, and RTSs, suggests that the increased movement rates correlate to general instability, and even at their current distances, FDLs are impacting infrastructure through increased sediment mobilization. FDLA is the largest of the investigated FDLs. As of August 2015, FDL-A was $39.2 \mathrm{~m}$ from the toe of the Dalton Highway embankment. Based on its current distance and rate of move-
\end{abstract}

ment, we predict that FDL-A will reach the Dalton Highway alignment by 2023 .

\section{Introduction}

An atmospheric temperature rise has been identified as unequivocal by the Intergovernmental Panel on Climate Change (IPCC), with greater and faster temperature increase and an overall precipitation increase demonstrated at northern latitudes (Stocker et al., 2013). Analysis of field data collected throughout Arctic and subarctic areas corroborates with IPCC's findings, demonstrating an overall permafrost temperature rise (Christiansen et al., 2010; Romanovsky et al., 2010; Smith et al., 2010). Slopes in permafrost areas are in danger of instability with rising temperatures. Increasing temperatures lead to deeper active layer depths, resulting in increased water infiltration; ice within the soil or debris melts, causing loss of soil strength, accelerated movement, and potential debris flows or total collapse (Deline et al., 2015; Geertsema et al., 2006; Gude and Barsch, 2005; Harris et al., 2008a, b; Lewkowicz and Harris, 2005; Swanger and Marchant, 2007). Slope instability presents a risk to adjacent infrastructure, especially where roads and utilities pass through mountainous regions. An increase in infrastructure construction may occur in northern regions, including Alaska, as Arctic countries focus on economic development (EOP, 2014; Sevunts, 2013). Thus, recognizing areas of slope instability and quantifying historic and potential movement become progressively important as climate changes and northern regions see increasing development. 
An example of previous development in the Alaskan Arctic was the construction of the Trans Alaska Pipeline System (TAPS) and supporting infrastructure, including the Dalton Highway, which opened a corridor within the Brooks Range. In the late 1970s and early 1980s, those mapping the geology and geologic hazards along the Dalton Highway corridor noted the presence of elongated, lobate features along slopes adjacent to the highway, thought to be inactive at that time (Hamilton, 1978, 1979, 1981; Kreig and Reger, 1982; Brown and Kreig, 1983). These features were "rediscovered" in 2008, partially due to the fact that they were indeed actively moving. When originally mapped, these features were identified as flow slides or rock glaciers; however, ongoing investigations indicate that they are different from rock glaciers in their source, composition, rate and mechanism of movement, and vegetation coverage (Daanen et al., 2012; Simpson et al., 2016). Because of these differences, these permafrost features were given the new name frozen debris lobes (FDLs) (Daanen et al., 2012). As the resolution of freely available satellite imagery improves, we continue to identify additional FDLs, with nearly 160 FDLs located thus far within the Brooks Range (Fig. S1 in the Supplement).

Field investigations of FDLs began in 2008 with preliminary differential global positioning system (DGPS) measurements, soil pits, and field observations on FDL-A, with some work on nearby FDL-B, FDL-C, and FDL-D (Daanen et al., 2012). Field work continued with a 2012 subsurface investigation of FDL-A (Simpson et al., 2016), and we expanded the area of interest (AOI) in 2013 to comprise eight FDLs (Fig. 1). Since expanding the investigation, we have traveled to the field two to three times a year to collect DGPS measurements of the FDL surfaces, as well as samples of soil, rock, water, and ice. Our field investigations and observations led us to the following questions. (1) How does the bedrock source geology contribute to FDL morphology? (2) Are the investigated FDLs consistent in composition and morphology? (3) Has the movement of these FDLs been synchronous? (4) Have their rates of movement changed over time? (5) How can we describe the origin of these features? (6) How are FDLs impacting infrastructure? In an effort to answer these questions, in this paper we present for the first time a comprehensive overview of eight different FDLs within the Dalton Highway corridor. Within this overview, we detail catchment geology, measured rock strengths, lobe soil characteristics, and historic and current rates of movement.

\section{Study site and background}

The AOI is located in the south-central Brooks Range, within the Arctic Mountains physiographic division (Wahrhaftig, 1965). This area is underlain by continuous permafrost (Jorgenson et al., 2008). Daanen et al. (2012) provided an overview of the historic temperatures of the area, as well as

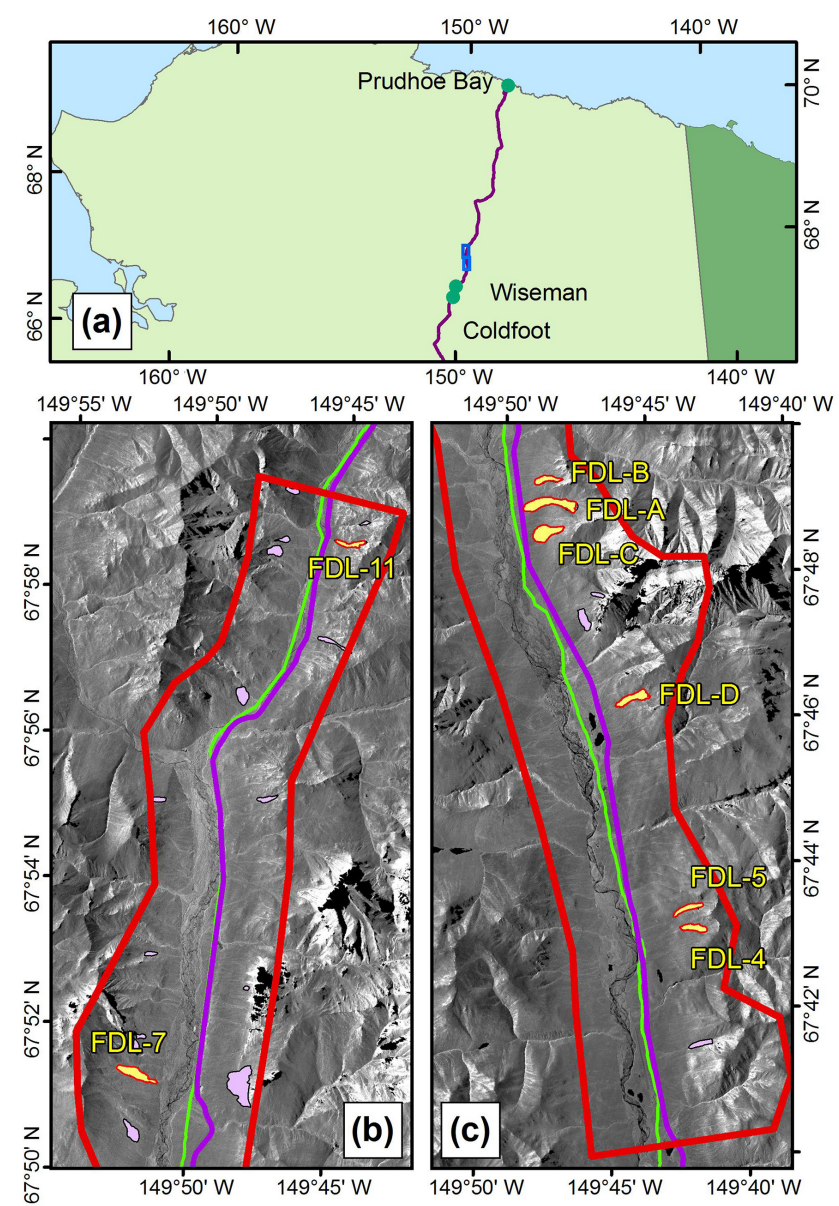

Figure 1. Map of the study area. (a) Location relative to communities along the Dalton Highway (shown in purple); blue rectangular insets show locations of area of interest (AOI). The northern and southern portions of the AOI (in red) are shown in (b) and (c), respectively. The eight investigated FDLs are shown in yellow and labeled; other FDLs within the AOI are shown in lavender. The TAPS alignment is indicated in green; within the AOI the infrastructure parallels the Dietrich River. (Base map data from ASGDC, 2014 and GINA, 2001.)

initial descriptions of four FDLs and preliminary characterization of movement processes. FDL-A is the largest frozen debris lobe within the AOI, and the closest to the Dalton Highway (Fig. 2a). Due to its close proximity to infrastructure and thus greater potential risk, some of the authors conducted a subsurface investigation of FDL-A jointly with the Alaska Department of Transportation and Public Facilities in September 2012 (Darrow et al., 2012, 2013). We drilled a total of eight boreholes, four on and four adjacent to FDL-A to the south and west. The borings ranged between 3.0 and $30.5 \mathrm{~m}$ deep. In several of the borings, we installed slotted casing for inclinometer measurements and thermistor strings; in the $30.5 \mathrm{~m}$ deep boring within FDL-A, we installed an automated Micro-Electro-Mechanical Systems (MEMS)-based in-place inclinometer (M-IPI), two vibrating-wire piezome- 


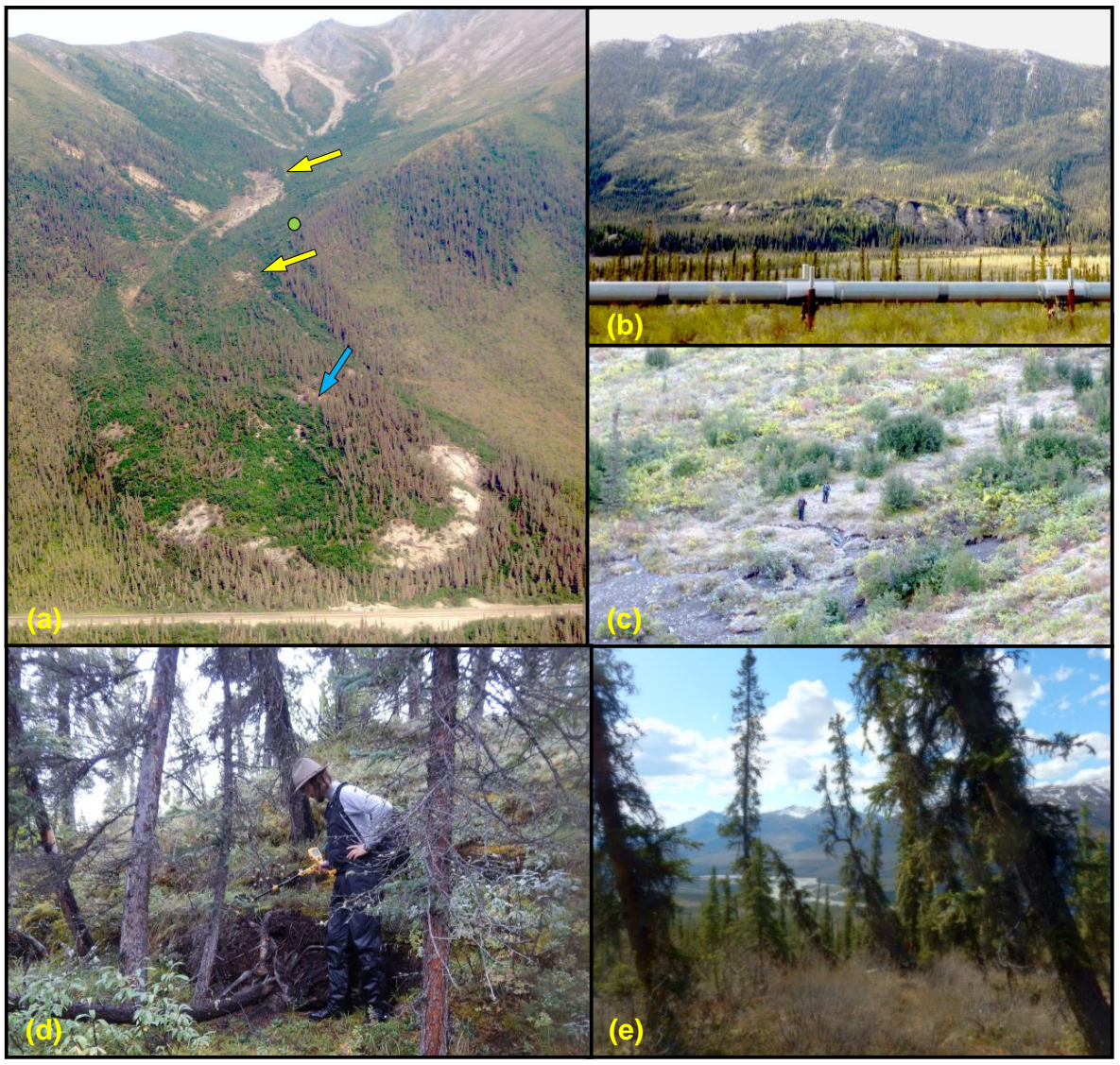

Figure 2. Typical FDL appearance, lobe, and catchment features. (a) FDL-A, originating from a cirque-like catchment; the Dalton Highway is in the foreground (photograph taken in June 2013). Yellow arrows indicate locations of two retrogressive thaw slumps (RTSs), the blue arrow indicates the location of the 2012 instrumented borehole, and the green dot is the location of the sampled organic layer. (b) FDL at the base of a slope outside of the AOI that may have formed from a paleolandslide deposit. The Trans Alaska Pipeline is in the foreground. (c) FDL-11 catchment, showing typical vegetation and recent scarp; two people stand above the scarp for scale. (d) Riser of smaller surface lobe on FDL-C. (e) Trees near the right flank lean progressively towards the center of FDL-5.

ters, and a thermistor string (the location of this main instrumented borehole is indicated in Fig. 2a). Simpson et al. (2016) summarized the geotechnical investigation, presenting measured temperatures and slope movement data, the results of strength testing of frozen soil samples, a slope stability analysis, and the initial results of a geographical information system (GIS) protocol by which to examine FDLs.

Results from these investigations indicate that FDLs are mainly composed of a fine-grained soil matrix, but also contain rocks and organic debris. Subsurface measurements within FDL-A indicate that this frozen debris lobe moves predominantly through shear in a zone 20.6 to $22.8 \mathrm{~m}$ below ground surface (bgs), with temperature-dependent internal flow as a secondary movement mechanism (Darrow et al., 2015; Simpson et al., 2016). For example, between September 2012 and August 2015, FDL-A moved $13.8 \mathrm{~m}$ through shear and only $1.9 \mathrm{~m}$ through internal flow, for a total displacement of $15.7 \mathrm{~m}$ at the main borehole location. The significant movement within the shear zone severed the instru- mentation approximately 1 month after its installation; however, we are still able to collect subsurface temperature and movement measurements from the upper $20.6 \mathrm{~m}$ of the MIPI. Temperatures measured from 15 to $20.6 \mathrm{~m}$ from January 2014 through August 2015 were stable at $-0.85^{\circ} \mathrm{C}$, whereas the temperature of the adjacent permafrost at $3 \mathrm{~m}$ from the same time period was $-2.1^{\circ} \mathrm{C}$.

\section{Methods}

\subsection{Fieldwork and sample collection}

We selected eight FDLs based on size, evidence of movement, and proximity to the Dalton Highway to assess their geohazard potential. We installed surface marker pins to determine current rates and spatial variability of surface movement, beginning with FDL-A in late October 2012. In June 2013, we continued the installation on the other seven investigated FDLs. On each lobe, the surface marker pins 
Table 1. Summary of available imagery used for historic analysis. USGS is the US Geological Survey, AHAP stands for Alaska HighAltitude Photography, and DGGS is the Alaska Division of Geological \& Geophysical Surveys. If all FDLs are covered by a given data set, "none" is stated under limitations.

\begin{tabular}{llll}
\hline Year & Source & $\begin{array}{l}\text { Resolution } \\
(\mathrm{m})\end{array}$ & $\begin{array}{l}\text { Limitations in } \\
\text { FDL coverage }\end{array}$ \\
\hline 1955 & USGS (aerial) & 1.78 & none \\
1970 & AHAP (aerial) & 2.0 & none \\
1978 & AHAP (aerial) & 1.5 & no FDL-5, FDL-4 \\
1979 & AHAP (aerial) & 1.5 & only FDL-11, FDL-7, FDL-B \\
1981 & AHAP (aerial) & 1.5 & only FDL-D, FDL-5, FDL-4 \\
1993 & Quantum spatial (aerial) & 0.3 & none \\
2007 & DigitalGlobe Ikonos (satellite) & 1.5 & only FDL-7, FDL-B \\
2009 & DigitalGlobe WorldView (satellite) & 0.5 & no FDL-11 \\
2011 & DGGS (lidar) & 1.0 & none \\
2014 & DigitalGlobe WorldView (satellite) & 0.5 & none \\
\hline
\end{tabular}

were positioned along a longitudinal profile from the catchment to the lobe toe, and along at least one cross-sectional transect. We made repeated measurements of all surface marker pins in August 2013, June and August 2014, and May and August 2015, with additional measurements of FDL-A twice in November 2012 and in March or April of each year. Measurements were made with a DGPS unit, having horizontal and vertical accuracies of $\pm 5 \mathrm{~cm}$. We also located and mapped easily visible scarps in the less-vegetated catchment areas with a hand-held GPS. RTSs are present in several FDL catchments and on the lobes; we repeatedly mapped their head scarps to determine rates of regression.

We collected rock and soil samples (Fig. S2) to determine rock strengths and soil engineering index properties. We sampled rocks from the catchment areas for strength testing, while also updating the pre-existing geologic map of the area (Spangler and Hubbard, 2016). Tests were made with a hydraulic point load testing device to determine the rocks' point load strength indices, which were converted to uniaxial compressive strengths. On each lobe, we dug two $1 \mathrm{~m}$ deep soil pits, examining the near-surface soils and collecting samples for standard engineering index property testing, including moisture content (ASTM D2116), organic content (modified from AASHTO T267), grain size distribution (AASHTO T27/T11, ASTM D422), and plasticity (ASTM D4318) (AASHTO, 2009; ASTM, 1990, 1998, 2000). All soil classifications are based on the Unified Soil Classification System (USCS).

Field observations and subsequent analysis of lidar data indicated the presence of relatively flat benches along the catchment slopes on either side of FDL-A. Hypothesizing that the benches represented the paleosurface of FDL-A before its downslope movement began, in August 2015 we sampled buried organic material from a trench in the active layer on the south bench (see green dot in Fig. 2a). We submitted the sampled organic soil to Beta Analytic, Inc. for radiocarbon dating. This laboratory service calibrated the results using databases associated with the 2013 INTCAL program (Reimer et al., 2013); the resulting 2-sigma calendar calibration range is presented herein.

The summer of 2014 was the wettest on record for parts of interior Alaska, with rainfall exposing massive ice in several RTSs on FDL-7, FDL-A, and FDL-D. In August 2014 we collected samples of exposed ice on FDL-A in the lower RTS near the left flank (see lower yellow arrow in Fig. 2a), and water samples from the creek that drains FDL-A and a puddle adjacent to the lobe during a major rain event; in March 2015, we collected two samples of snow from the lobe. These samples were submitted for analysis to the Alaska Stable Isotope Facility at the University of Alaska Fairbanks' Water \& Environmental Research Center. Stable isotope data were obtained using continuous-flow isotope ratio mass spectrometry. The $\delta^{2} \mathrm{H}$ and $\delta^{18} \mathrm{O}$ values were measured using a ThermoScientific high temperature elemental analyzer (TC/EA) and Conflo IV interface with a DeltaVPlus Mass Spectrometer. Stable isotope ratios were reported in $\delta$ notation as parts per thousand $(\%)$ deviation from the international standards, V-SMOW (Standard Mean Ocean Water). Typically, instrument precision is $<3.0 \%$ o for hydrogen and $<0.5 \%$ o for oxygen. We compared the results obtained against the Global Meteoric Water Line (GMWL) and isotope values from massive ice bodies taken from the literature.

\subsection{Historic image collection and analysis}

We acquired aerial and satellite imagery for the AOI from years between 1955 and 2014 (Table 1); images for each data set were compiled into mosaics using the Agisoft Photoscan and ENVI software. The mosaics were orthorectified according to the American Society of Photogrammetry and Remote Sensing's (ASPRS) horizontal accuracy standards (ASPRS, 2015). In a GIS environment, we used contour lines derived from digital elevation models (DEMs) produced from 2011 lidar and 2001 Interferometric Synthetic Aperture Radar (If- 
SAR) data ( 1 and $5 \mathrm{~m}$ resolution, respectively), GPS measurements, and field observations as references for determining catchment and 2011 lobe extents. Next, we determined the extent of each lobe for each year of available imagery (spatial limitations in imagery coverage are summarized in Table 1). Because the FDLs demonstrate only minor lateral spreading, longitudinal profile polylines oriented along the center of each lobe served as the consistent reference from which to measure changes. The distance between each pair of toe locations measured along the longitudinal center line for two data sets was divided by the time interval between data years, resulting in an average movement rate for the time interval. Each rate was assigned to the latter of the two data years. Although not part of the rate analysis, we also include assessment of 2001 and 2002 Google Earth images of the $\mathrm{AOI}$ in the discussion.

\section{Results}

\subsection{Catchments and rock data}

Frozen debris lobes typically originate from catchments (Fig. 2a), many of which may have supported small cirque glaciers during early to mid-Pleistocene glacial advances in the area (Hamilton, 1986). In some cases, FDLs have formed at the base of a slope rather than a catchment, from the accumulation of loose colluvium (e.g., FDL-C), or from landslide deposits (Fig. 2b). The catchments of the eight FDLs presented here range from $121000 \mathrm{~m}^{2}$ (FDL-B) to $801000 \mathrm{~m}^{2}$ (FDL-A), with an average size of $414000 \mathrm{~m}^{2}$ (Table S1 in the Supplement).

The catchments of the investigated FDLs range from bowllike and well-defined (FDL-11, FDL-B, FDL-A, FDL-D, FDL-5), to flatter with more open slopes (FDL-7, FDL-4). The upper portions of the catchments consist of exposed rock talus and solifluction lobes supporting shrubby vegetation (Fig. 2c). The major sources of debris coming into the catchments are rockfall and solifluction (Daanen et al., 2012; Spangler et al., 2013).

The bedrock contributing to the studied catchment areas consists of heavily fractured, metasedimentary and metavolcanic rocks, including phyllite, slate, metasiltstone, metasandstone, greywacke, and conglomerate, with minor amounts of limestone, marble, and igneous intrusions (Fig. S2; see Table S2 for rock unit descriptions). The joint spacing is typically less than $30 \mathrm{~mm}$. The rocks tested had strengths ranging from 14.0 to $77.3 \mathrm{MPa}$ (Fig. S2, Table S1), which covers the range from very low strength to medium strength (Kehew, 2006). It should be noted that testing was conducted on samples that were competent enough to be collected and transported from the field, which suggests that these strength values are an overestimate of the actual rock strengths in the field area. While the bedrock in each catchment consists of different units, the commonality among all catchments is the predominance of heavily fractured, platy, foliated rocks. Additionally, while some samples demonstrated medium strength values, the test results and associated bedrock geology indicate that most of the catchment areas are underlain by very low- to low-strength rocks. The combination of low strength and a high degree of fracturing suggests that much of the bedrock can be treated as dense coarse soil (Milligan et al., 2005), thus easily contributing to the formation of mass movement features such as FDLs.

\subsection{Frozen debris lobe composition and morphology}

FDLs are elongated lobate features. The areas of the eight FDLs presented here range from $83000 \mathrm{~m}^{2}$ (FDL-11) to $286000 \mathrm{~m}^{2}$ (FDL-A), with an average area of $149000 \mathrm{~m}^{2}$. Their length-to-width ratios typically range from $4: 1$ to $7: 1$ (Table S3). An exception is FDL-C, with a length-to-width ratio of $2: 1$. The rounder appearance of this lobe is most likely due to its origin at the base of a slope rather than in a catchment, which limits both its supply of debris and water. Most notable about the surface of FDL-C are the smaller, superimposed surface lobes that form as the mass moves downslope (Fig. 2d). These features are present on several other lobes, including FDL-A. Analysis of subsurface data suggests that the surface lobes form as faster internal flow within the active layer becomes sandwiched between the cooling surface and the rising permafrost table in the fall (Darrow et al., 2015). Soil pits excavated into the top $1 \mathrm{~m}$ of several of the lobes contained buried organic layers, possibly buried as the surface was overrun by uphill material in a surface lobe.

A special case of buried organic material was manifested on the south bench of FDL-A. The trench dug into the active layer at this location exposed the transition of colluvium (brown organic silt) into FDL-A lobe soil (gray silty sand with gravel). Within the lobe soil, we intercepted a buried organic layer that was submitted for radiocarbon dating; the calibrated result ( $95 \%$ probability) indicated a time of burial between Cal AD 1220 to 1285 .

FDLs are composed of platy rocks typical of their catchments, organic debris such as trees and shrubs, and a soil matrix composed of silty sand with varying amounts of gravel, all of which is frozen (Table S3). Where sampled, the upper $1 \mathrm{~m}$ of tested FDL soils was moist to wet and slightly organic to organic. Similar tests were conducted on the subsurface samples obtained from the 2012 drilling on FDL-A. Samples were collected from depths ranging from 2.9 to $24.8 \mathrm{~m} \mathrm{bgs}$, and tested uniformly as wet (when thawed) silty sand with gravel (Table S3), indicating a consistency in the soil gradation and moisture content with depth that may occur for all FDLs. Boreholes from the 2012 subsurface investigation intercepted no massive ice, and all samples obtained from the drilling were ice-poor (i.e., samples contained no excess ice and volumetric moisture contents (averaging $31 \%$ ) were less than the calculated porosity of the soil). 
While the sampled soils were ice-poor, in striking contrast massive ice does exist within the FDLs. Over several years, we measured and observed the changes of two RTSs on FDLA's surface (Fig. 2a). Figure 3 contains photographs of the change in the upper RTS, which retreated up to $20 \mathrm{~m}$ between 2011 and 2015 due to the melting of massive ice.

There are several different origins of massive ice in periglacial regions (Davis, 2001; Washburn, 1985; Williams and Smith, 1989); we propose that the ice exposed in the FDLs is infiltration ice, which forms when surface runoff (from rain or snowmelt) enters into cracks in the ground and quickly freezes. Tarussov (1992) used the term "infiltration ice" to describe a similar phenomenon produced as summer melt infiltrates glacial ice. The ice we observed in the RTS head scarps was clear, consisting of large crystals, and containing bubbles and strands of fungus (Fig. 4a, inset). Observations of the head scarp in the lower RTS further support the infiltration ice origin. The exposed massive ice corresponded with an open surface crack with a buried organic layer vertically offset to its right and left, indicating extension and downslope movement (Fig. 4a).

Figure $4 \mathrm{~b}$ is a presentation of the isotope analysis results with the GMWL and isotope values from massive ice bodies taken from the literature, including Pleistocene wedge ice near Fairbanks, Alaska (Douglas et al., 2011), late glacial and Holocene wedge ice near Barrow, Alaska (Meyer et al., 2010), and a suite of wedge ice samples ranging in age from Pleistocene to recent from northern Siberia (Meyer et al., 2002). This collection of data indicates that the oldest ice has the lightest isotopic composition, which becomes heavier with decreasing age. The infiltration ice sample from FDL-A is bracketed by recent and subrecent wedge ice. The heavy isotopic composition of the sampled ice and its similarity to the creek and puddle samples supports the hypothesis that infiltration ice forms predominantly from rain water entering cracks open at the surface.

\subsection{Frozen debris lobe movement rates}

Figures 5 and 6 are vector maps, illustrating the amount of movement measured on the lobe surfaces between June 2013 and August 2015, as well as RTS head scarp retreat. The lobes were divided into those demonstrating between 6 and $45 \mathrm{~m}$ of movement (Fig. 5), and those demonstrating less than $6 \mathrm{~m}$ of movement (Fig. 6) during the measurement period. Movement is generally parallel to each FDL's longitudinal profile. Levees that formed along the lobe flanks demonstrate a component of movement away from the center line, indicating some spreading of the lobe along its periphery (see FDL-7, FDL-A, FDL-C, and FDL-4 as examples). Additionally, the levees move more slowly than the rest of the lobe. We observed a notable example of this differential movement in August 2014 on FDL-7 when a recent debris flow along the levee margin was sheared forming echelon cracks within the young deposit. The average rates of movement for all

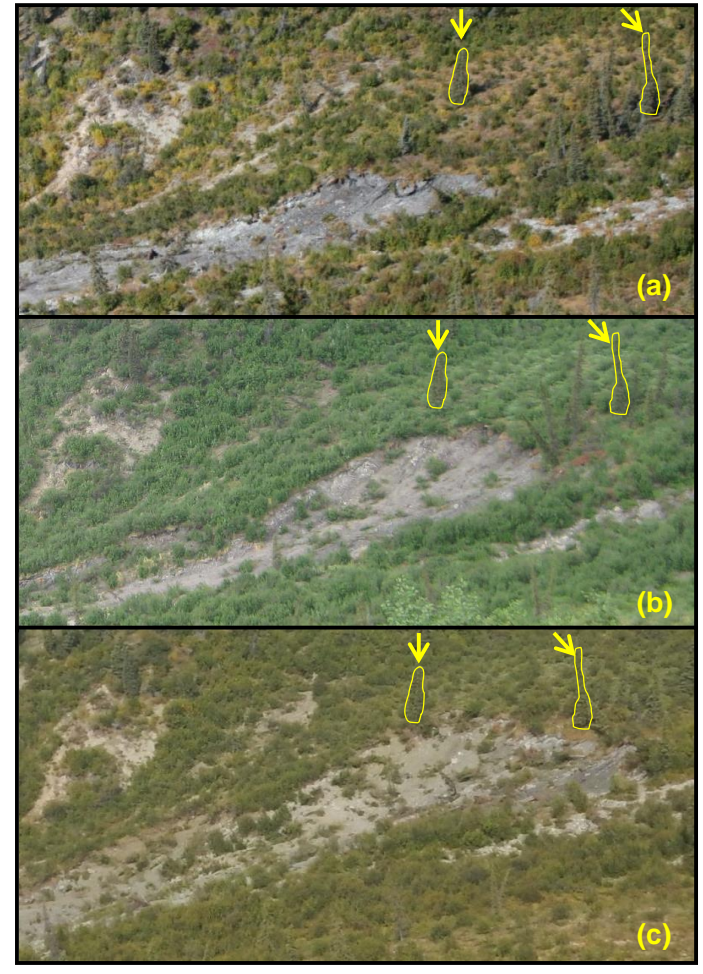

Figure 3. Retrogressive thaw slump (RTS) development on FDL-A: (a) August 2008; (b) June 2013; (c) August 2015. Arrows and outlines indicate the same two trees in all three images for comparison.

FDLs for the 2013-2014 and 2014-2015 measurement periods are presented in Table S3. These values exclude measurements taken on levees or above the lobes in their catchments. The 2014-2015 rates range from $0.2 \mathrm{~m} \mathrm{yr}^{-1}$ for FDL-11 to $13.3 \mathrm{~m} \mathrm{yr}^{-1}$ for FDL-D, with FDL-A falling in between at $5.2 \mathrm{~m} \mathrm{yr}^{-1}$.

\subsection{Analysis of historic imagery}

Figure 7 is a presentation of the change in extent of the eight investigated FDLs from 1955 to 2014, and changes in movement rates over this period are presented in Fig. 8 (see Table S4 for a rate summary). The eight FDLs can be divided into two general groups, those with increasing rate trends (either steadily or rapidly increasing; Fig. 8a and b, respectively), and those with decreasing rate trends (Fig. 8c). Only two of the eight FDLs have decreasing rate trends.

Analysis of the visual progression and rates indicates that movement of these FDLs has been asynchronous over the study period. For example, FDL-11 advanced nearly $10 \mathrm{~m} \mathrm{yr}^{-1}$ in the 1970s, faster than any of the other FDLs at that time; however, our surface marker measurements indicate that FDL-11 is currently moving only $0.2 \mathrm{~m} \mathrm{yr}^{-1}$. In contrast, FDL-D experienced a rapid increase in movement in recent years, moving an average $32.1 \mathrm{~m} \mathrm{yr}^{-1}$ between 2009 and 2011, with FDL-7 and FDL-5 demonstrating the 

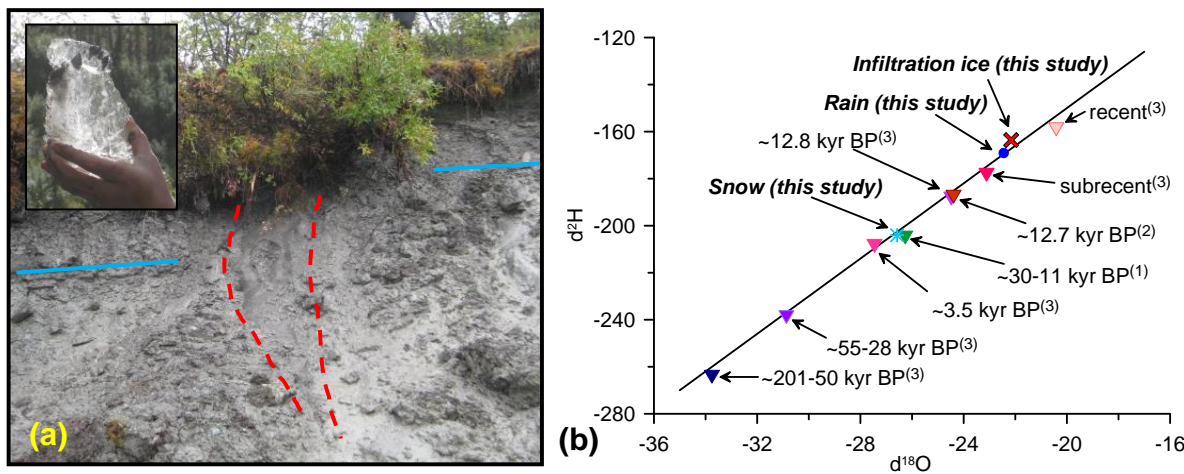

Figure 4. Infiltration ice in FDL-A. (a) Massive ice (outlined by red dashed lines) exposed in RTS along the left flank in August 2014 (see Fig. 2a for location). Offset buried organic layers are indicated by solid blue lines; inset shows an example of clear infiltration ice. (b) Isotope analysis results; the GMWL is plotted for comparison. Upside-down triangle symbols represent wedge ice sample values; values taken from the literature are from Douglas et al. $(2011)^{(1)}$ and Meyer et al. $\left(2010^{(2)}, 2002^{(3)}\right)$.

next largest increases in movement rates. FDL-A, on the other hand, has demonstrated a steady increase in its movement rate since 1955 , fitting a linear trend with a coefficient of correlation $\left(R^{2}\right)$ of 0.88 over this period.

\section{Discussion}

Much work has been done to describe and categorize mass wasting features on permafrost-stabilized slopes in mountain regions (French, 2007; Gorbunov and Seversky, 1999; Gruber and Haeberli, 2007; Haeberli et al., 2006; Humlum, 1998a; Kääb et al., 2007; Matsuoka et al., 2005; Wahrhaftig and Cox, 1959). FDLs are the latest features to be defined (Daanen et al., 2012), taking their place in the continuum of mass movement processes. Since FDLs were referred to previously as rock glaciers, we include a brief summary of these features for comparison. Rock glaciers are described in many cold climate regions (Ballantyne et al., 2009; Barsch, 1977; Berthling et al., 2003; Bollman et al., 2015; Brenning and Azocar, 2010; Calkin et al., 1998; Farbrot et al., 2007; Haeberli and Vonder Mühll, 1996; Haeberli et al., 1998, 2006; Humlum, 1998a, b; Ikeda and Matsuoka, 2006; Ikeda et al., 2008; Isaksen et al., 2000; Kääb et al., 1997; Krainer et al., 2015; Wahrhaftig and Cox, 1959; Wirz et al., 2016), forming on talus slopes, at the base of cliffs, or within cirques (Davis, 2001; Embleton and King, 1975). In terms of lobe geometry, Matsuoka et al. (2005) describe a classification for rock glaciers and solifluction lobes. FDLs most resemble these authors' description for "pebbly" rock glaciers; however, the dimensions of FDLs are much greater with a notably different composition. Rock glaciers often support surfaces covered by blocky cobble/boulder-sized debris, underlain by ice-supersaturated finer material, which consists of sand and gravel with little silt or clay (Embleton and King, 1975; Haeberli and Vonder Mühll, 1996; Haeberli et al., 1998; Ikeda and Matsuoka, 2006; Krainer et al., 2015; Wahrhaftig and
Cox, 1959). It is typical for the subsurface ice-supersaturated layer to be 50 to $90 \%$ ice by volume, and geophysical soundings and drilling indicate a stratigraphy of coarse blocky material, underlain by ice-rich soils, underlain by another coarse basal layer (Haeberli et al., 1998; Krainer et al., 2015). Unlike rock glaciers, FDLs are "homogeneously heterogeneous"; that is, they are composed of silty sand with varying amounts of gravel. Drilling in FDL-A and visual observations of exposures on all of the lobes indicate this consistent mix of soil with depth. While cobbles and boulders do exist on and within these features, they are a minor component and do not form distinct horizons.

The large volume of ice within rock glaciers allows for their movement through steady-state creep, with the younger, stratigraphically higher layers moving faster than the older, deeper layers (Haeberli and Vonder Mühll, 1996; Haeberli et al., 1998). Since the creep rate decreases with decreasing ice content for volumetric ice contents less than $65 \%$ (Arenson et al., 2015), the slower creep rate with depth may be related to rock glacier stratigraphy. Rock glaciers move $1 \mathrm{~m} \mathrm{yr}^{-1}$ or less, although recent measurements show rates as high as $6.3 \mathrm{~m} \mathrm{yr}^{-1}$ (Micheletti et al., 2015; Wirz et al., 2016). FDLs move at rates an order of magnitude greater than those typical of rock glaciers. While measurements from FDL-A indicate a component of internal flow/creep, this mechanism of movement is minor, contributing only $12 \%$ to the overall movement rate. Instead, FDL-A - and other FDLs based on field observations - move mostly by shear in zones near their bases. This is similar to the findings of Krainer et al. (2015), who documented an ice-cemented rock glacier that moved mainly in two shear horizons, with internal deformation contributing minor movement (albeit at a much slower rate than FDLs).

Another characteristic of FDLs that sets them apart from rock glaciers is their vegetative cover. Rock glaciers that are mostly or completely covered by vegetation are relict features (Krainer et al., 2015). In contrast, many of the FDLs 

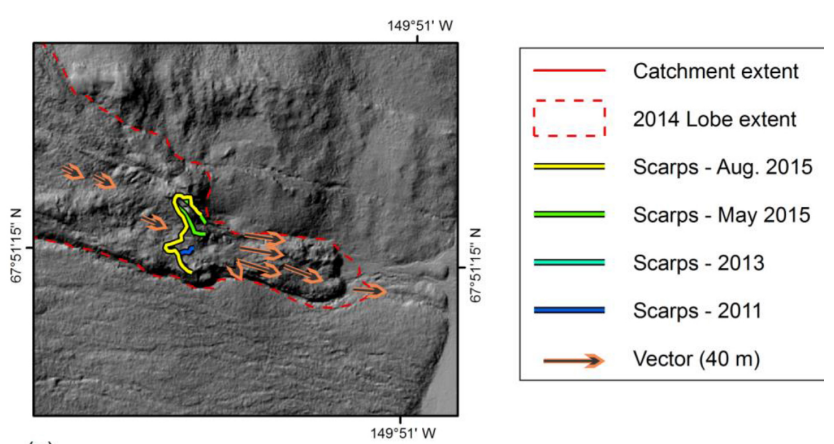

(a)

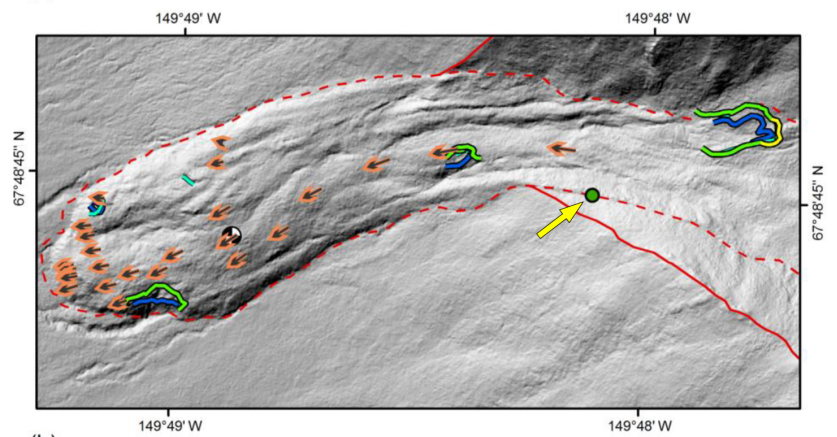

(b)

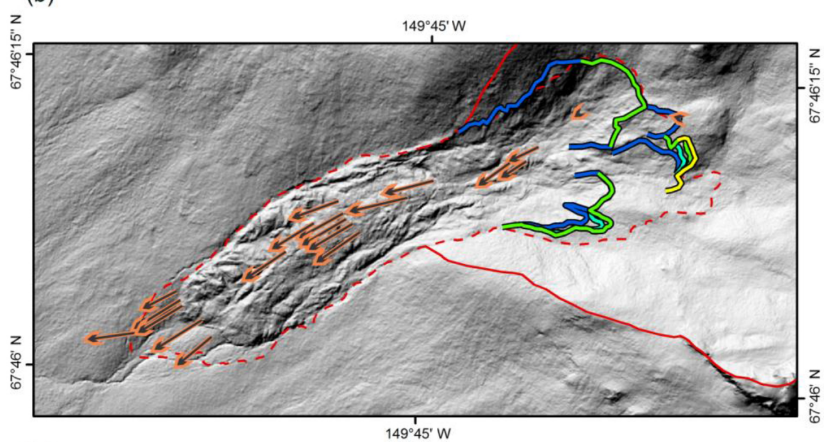

(c)

Figure 5. Vector maps of (a) FDL-7, (b) FDL-A, and (c) FDL-D, summarizing movement measured from June 2013 to August 2015, and RTS development. The scale of each image is $1: 10000$. Vectors are scaled from the $40 \mathrm{~m}$ scale included in the legend. The arrow and the green dot in (b) indicate the location of sampled organics for radiocarbon dating, and the location of the 2012 borehole on FDL$\mathrm{A}$ is indicated by the white and black symbol. As the base maps are from 2011 lidar data (Hubbard et al., 2011), the 2014 FDL extents are also shown.

within the Dalton Highway corridor support mature white spruce forests on their surfaces and all support brushy vegetation; the trees indicate movement of the underlying, active FDL by their orientations away from vertical. Occasionally, active forested rock glaciers do exist, such as Tien Shan rock glaciers in central Asia (Sorg et al., 2015) and the Slims River lobate rock glacier in Canada (Blumstengel and Harris, 1988); however, their slower rates of movement and composition differentiate these rock glaciers from FDLs.

Haeberli et al. (1998) presented a discussion of how the multilayered structure of rock glaciers forms, and Haeberli and Vonder Mühll (1996) suggested that many rock glaciers in the European Alps have been in existence since the beginning of the Holocene. Recent work by Krainer et al. (2015) on a rock glacier in the Italian Alps verified its formation nearly 10300 years ago. Similar ages are suggested for rock glaciers in Alaska's northern and central Brooks Range, with rock glaciers forming from increased rockfall from oversteepened valleys and cirque walls after Pleistocene glacial retreat (Calkin et al., 1987; Ellis and Calkin, 1984).

In the southern Brooks Range, the catchments within the AOI supported cirque glaciers during the Itkillik I advance (110-60 ka), but subsequent advances were not as extensive (Hamilton, 1978, 1986); thus, these catchments may have been ice-free longer than the Holocene. With the retreating ice, debris accumulated in the catchment bottoms. The platy and weak rocks typical of the area weathered to form the silty sand with gravel soil matrix comprising FDLs. As the AOI was propitious for the formation of permafrost, the debris froze as it accumulated, providing rheological properties that both countered erosional processes and allowed flow. Accumulation continued until the debris reached a "critical mass" and began to flow out of the catchment areas. The recharge of the debris in the catchment areas is at a much slower rate than the movement rates of the individual lobes; thus, this is the first and only journey these specific features will make downslope. As indicated by Daanen et al. (2012), the end of this mass movement process is an alluvial fan that forms when an FDL completely destabilizes or when it reaches the river in the valley bottom, which removes the toe.

When did these FDLs begin to flow from their catchments? The answer to this question is important to build a framework from which to evaluate the risk these features pose to the adjacent infrastructure, and here we focus on FDL-A. FDL-A is farther downslope than any of the other lobes, which suggests that it either began to flow out of its catchment earlier or experienced rapid downslope movement. The benches present on either side of its lower catchment may represent its paleosurface before downslope movement began. Recreating the lobe within the catchment at this level provides a rough volume estimate of $1450000 \mathrm{~m}^{3}$ (Fig. 9). The sampled organic layer from within the bench was buried (possibly by debris flow deposits) as the lobe surface was actively building. Based on the radiocarbon date, the bulk of the lobe moved downslope around 730 to 795 years ago, leaving behind the benches and the buried organic material at the lobe's original elevation. While this interpretation is based on only one date from one site on FDL-A, it provides a general time frame for this stage of lobe development.

Downslope movement of an FDL causes tension and shearing, resulting in the formation of surface cracks. All of the investigated FDLs support numerous transverse and longitudinal cracks, and we suspect that these cracks contain infiltration ice. As a crack opens due to movement, water entering the crack freezes forming infiltration ice; the crack cannot close again, nor fill with debris. Thus, infiltration ice 


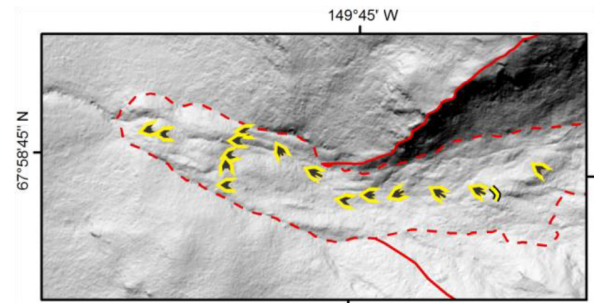

(a)

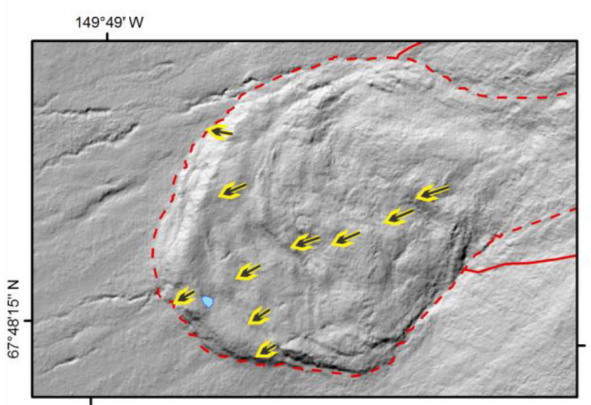

(c)

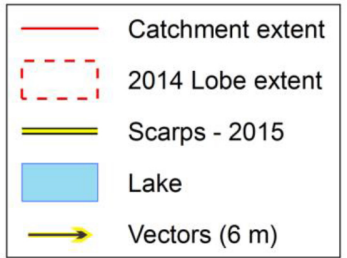

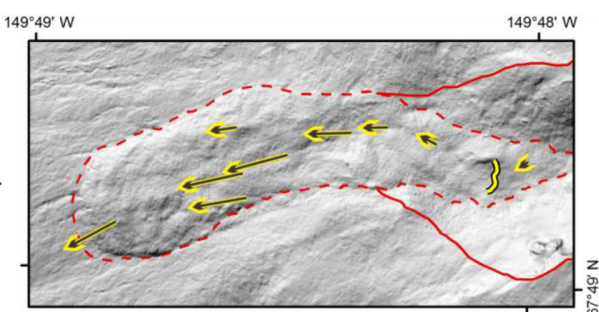

(b)

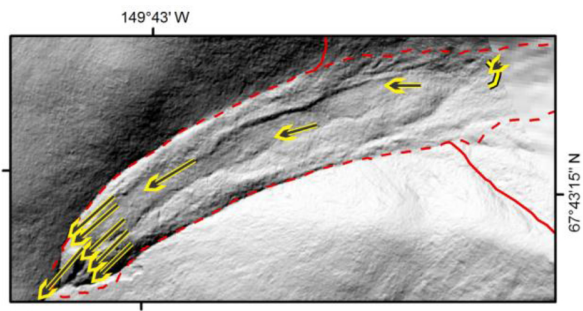

(d)

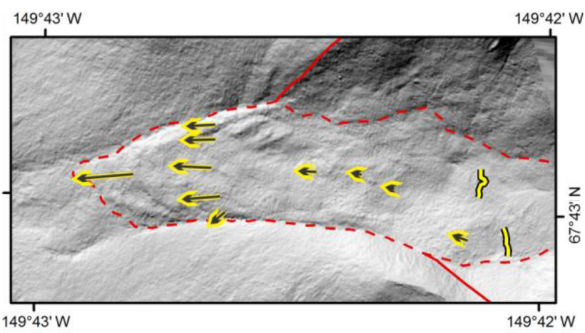

(e)

Figure 6. Vector maps of (a) FDL-11, (b) FDL-B, (c) FDL-C, (d) FDL-5, and (e) FDL-4 summarizing movement measured from June 2013 to August 2015, and scarp locations. The scale of each image is $1: 10000$. Vectors are scaled from the $6 \mathrm{~m}$ scale included in the legend. As the base maps are from 2011 lidar data (Hubbard et al., 2011), the 2014 FDL extents also are shown. Base maps also include data from GINA (2001).

contributes to FDL movement by providing additional lobe volume. An open, unfilled tension crack represents a break in the subsurface lateral stress distribution (Cornforth, 2005); however, if filled with ice, stresses developed in the upper lobe can be transmitted to the lower reaches. Finally, the ice volume must be considered with increasing temperatures. Increased melting of infiltration ice will lead to reduced soil strength and increased porewater pressure within the lobe (Simpson et al., 2016), which will accelerate FDL movement. Ikeda et al. (2008) documented a similar process in a rock glacier in the Swiss Alps; movement formed tensile cracks, allowing snowmelt to penetrate into voids, decreasing effective stress and increasing movement rates. Based on the number of surface cracks, an appreciable volume of the FDLs may be ice; however, we do not know how deeply these cracks penetrate the lobe. The volume and distribution of massive ice within FDLs may be determined through geophysical methods. Several methods - such as seismic refraction, georadar, and electrical DC resistivity - have yielded much information about the permafrost subsurface, including rock glaciers (Haeberli and Vonder Mühll, 1996; Hauck, 2013). Preliminary work on FDL-A indicates that induced polarization tomography (IPT) is a promising method to visualize the shear zone and any zones of liquid water within these features.

Not all of the FDLs are in the same state of downhill progression. Here we discuss three specific lobes that represent possible stages of FDL destabilization. Since beginning our field observations, we have noticed increasing signs of instability in FDL-5. Its surface appears to be "deflating" as evident by trees leaning towards its center on both the right and left flanks (Fig. 2e). This redistribution of mass resulted in over-steepening of the toe, measured at $\sim 44^{\circ}$ in 2015.

FDL-7 on the west side of the Dietrich River represents the next stage in destabilization. This lobe also deflated with trees leaning towards its center line; however, at this more advanced stage, the center has surged forward, forming a lower tongue shape (Fig. 10a). The lower tongue is actively and quickly changing, with large exposures of bare mineral soil and highly damaged spruce trees (Fig. 10b). On the flanks where the lower tongue begins, massive ice is exposed in RTSs that generate debris flows and provide another source of surface water during the summer months (Fig. 10c). Between May and August 2015, significant erosion occurred, 

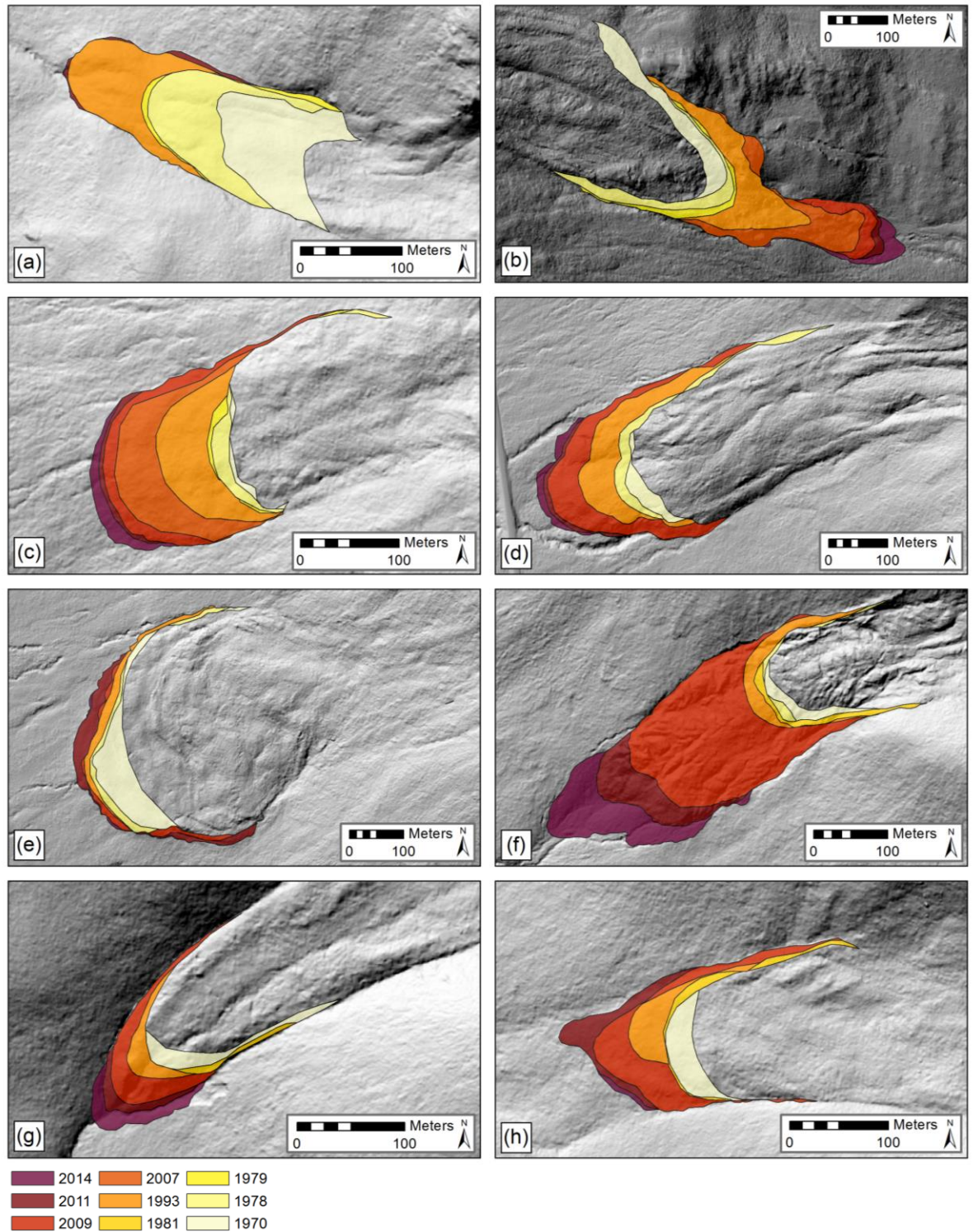

Figure 7. Change in FDL extent from 1955 to 2014: (a) FDL-11, (b) FDL-7, (c) FDL-B, (d) FDL-A, (e) FDL-C, (f) FDL-D, (g) FDL-5, (h) FDL-4. (Base maps from 2011 lidar data; Hubbard et al., 2011.)

merging the head scarps of RTSs near the right and left flanks of FDL-7 into one RTS that spans the entire width of the lower tongue (Fig. 5a).

The most advanced stage of destabilization is manifested in FDL-D. Between 1993 and 2001, an RTS formed in FDLD's lower catchment area. By 2010, transverse cracks in the catchment and longitudinal cracks along the levees were visible and persistent throughout the winter, indicating that the lobe was moving significantly throughout the year (see Fig. 11a for an example of transverse cracks within a winter aufeis deposit). Following the formation of the RTS, FDL-D rapidly moved $316 \mathrm{~m}$ downhill between 2002 and 2014. Although the northernmost scarp has not changed significantly since 2011, other active RTSs continue to enlarge. Our map- ping of two other RTSs indicated up to $38 \mathrm{~m}$ of head scarp retreat between 2011 and 2015 (Fig. 5c). These head scarps expose massive ice, which melts and contributes to debris flows. The debris flows cover much of the upper lobe area (Fig. 11b), provide additional sediment and water to the lobe, and increase the surface temperature of this already unstable permafrost feature.

Downhill of the catchment, the surface of FDL-D is a jumbled landscape, full of cracks, scarps, ponds, bare mineral soil, and crisscrossed vegetation that once was a mature spruce forest with a moss-covered ground surface. Figure 11c and $d$ are two examples of the landscape and extreme movement of the surface. In each photograph, a spruce tree is upside down with its roots (Fig. 11c) or trunk (Fig. 11d) ex- 

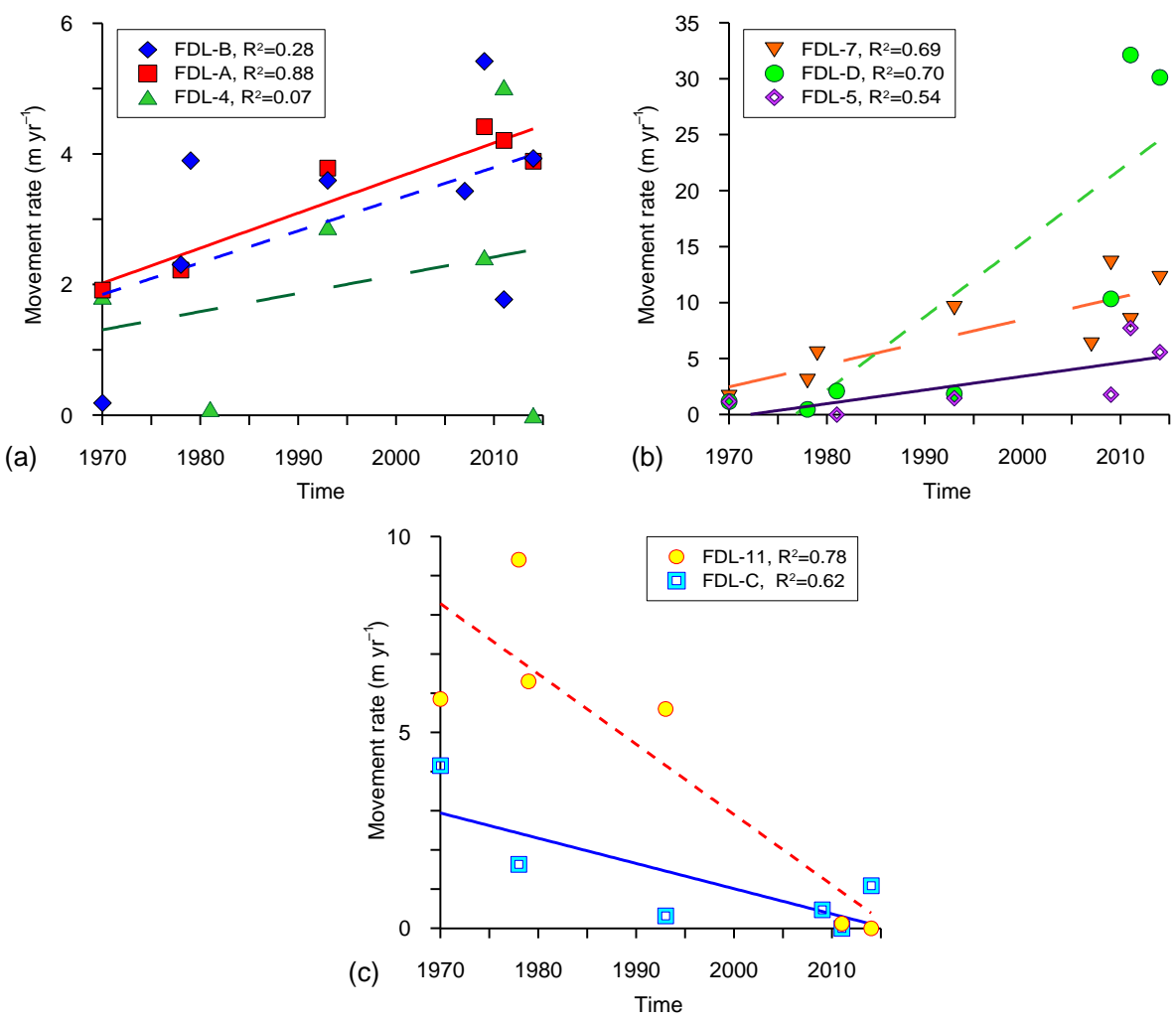

Figure 8. Historic FDL movement rates from 1955 to 2014 for lobes with (a) steadily increasing rates, (b) rapidly increasing rates, and (c) decreasing rates. The coefficient of correlations $\left(R^{2}\right)$ for linear trend lines fitted to each lobe data set are presented in the figure legends.

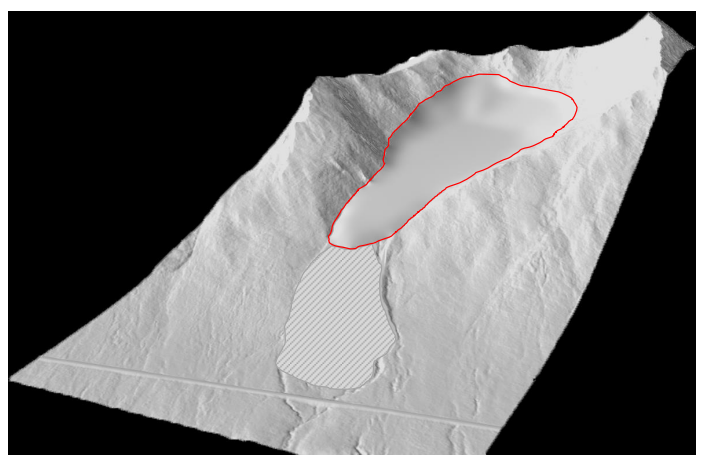

Figure 9. Reconstruction of paleosurface of FDL-A based on bench elevations in its catchment. The reconstructed lobe is outlined in solid red for visibility. The current lobe extent that was removed for the reconstruction is indicated by the area with gray diagonal lines. (Base map data from Hubbard et al., 2011.)

posed, while the rest of the tree is completely consumed by the lobe.

All of the investigated FDLs have scarps or RTSs in their upper reaches (Figs. 5 and 6). Analysis of the historic images and Google Earth satellite imagery indicates that the change in lobe morphology and formation of scarps on FDL7 occurred between 1979 and 1993. The scarps on FDL-A,
FDL-C, and FDL-D formed later between 1993 and 2002; the scarps on the other lobes are smaller and difficult to discern in the historic imagery. As mentioned above, the scarp on FDL-D evolved into an active RTS, and subsequently the lobe moved rapidly downslope. We hypothesize that RTS formation is a key step in FDL destabilization. The initial exposure of bare mineral soil increases the surface temperature, which causes infiltration ice to melt (Burn, 2000; Kokelj et al., 2009; Malone et al., 2013). The meltwater forms debris flows that cover a larger area of the lobe, changing the moss-covered surface to bare mineral soil, which increases the surface temperature and repeats the cycle (Gooseff et al., 2009). The debris flows also load the lobe surface with additional sediment, potentially providing the extra driving force needed to initiate downslope movement and the formation of transverse cracks. The meltwater can infiltrate through the now open cracks potentially to the basal shear zone, increasing porewater pressure and further accelerating the lobe's movement. More movement perpetuates this process, resulting in overall destabilization.

The underlying topography also may contribute to the destabilization of FDLs. Examination of the topographic maps generated from the 1955 imagery and the other historic images indicates that the drainages downslope of FDL11, FDL-7, FDL-D, and FDL-5 have topographic constric- 


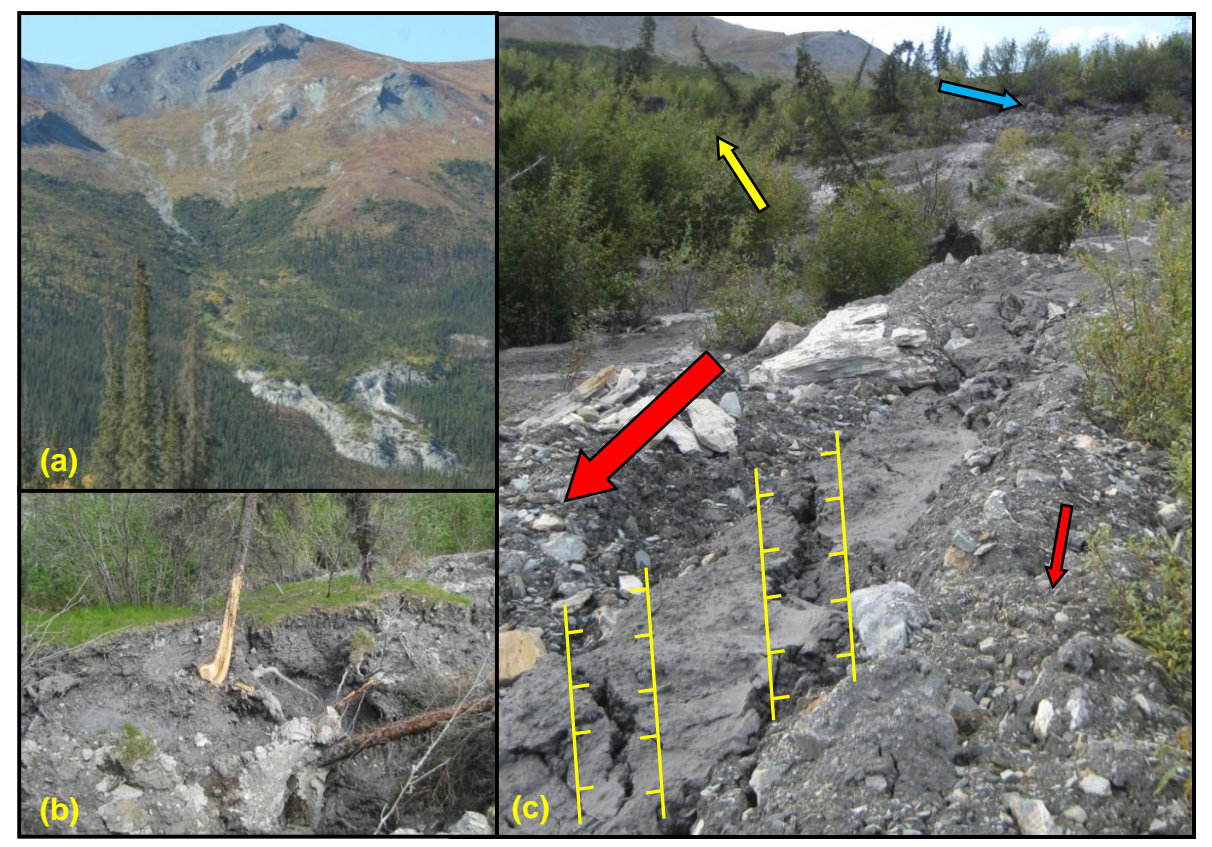

Figure 10. Features of FDL-7. (a) Deflation of the main lobe body towards the lower tongue, and the major RTSs along the right and left flanks. (b) Vegetation on the lower tongue, including a completely split spruce tree demonstrating about $20 \mathrm{~cm}$ of previous sedimentation along its trunk. (c) Along the left flank of the lower tongue of FDL-7, differing rates of movement are indicated by the larger red arrow on the lobe and the smaller red arrow on the levee (far right). Echelon cracks are annotated to show extension. The RTS that was the source of the debris flow is indicated by the blue arrow, and an area of leaning trees is indicated by the yellow arrow.

tions that impeded downslope movement of these lobes. The topographic constriction is most obvious for FDL-7. Sometime between 1979 and 1993, the lobe met this topographic narrowing, which halted the movement of the toe of the lobe; however, by 1993 a small portion of the lobe continued to flow forward, forming the lower tongue. The subsequent shearing along the flanks exposed infiltration ice, leading to growth of RTSs and acceleration of FDL-7's lower tongue. We suspect that FDL-5 is only now reaching a topographic constriction and may experience a similar destabilization and increase in movement in the near future.

The creeks draining the FDLs modify the permafrost downslope of the lobes, which also may contribute to accelerated movement. For example, we observe that the increased sediment load causes the creeks to jump out of their established channels, resulting in thermokarsts in the adjacent ice-rich soils (Gooseff et al., 2009). Often these creeks disappear within the permafrost, reappearing farther downhill as springs. This channel migration lowers the permafrost table, and increases ground temperature and porewater pressure, facilitating the movement of the lobe as it slides across the modified terrain. It is through their drainages that even the most-distant FDLs are impacting the infrastructure. The increased sediment mobilization from FDL movement and destabilization fills ditches and culverts, resulting in an overtopping hazard to the Dalton Highway and increased maintenance costs. Even FDL-7, which is across the Dietrich River from the Dalton Highway and TAPS (Fig. 1), may affect the infrastructure. The alluvial fan that is building in front of the lobe has the potential to shift the active Dietrich River channel to the east impinging on the TAPS alignment.

As of August 2015, the eight investigated FDLs range from about $1500 \mathrm{~m}$ (FDL-4) to less than $40 \mathrm{~m}$ (FDL-A) from the Dalton Highway (Table S3). Given the rate trends presented in Fig. 8, we can estimate when each FDL will intersect the highway embankment. Based on its 2015 distance of $39.2 \mathrm{~m}$, rate of $5.2 \mathrm{~m} \mathrm{yr}^{-1}$, and correlation coefficient for rate of movement, we predict that FDL-A will intersect the existing Dalton Highway alignment by 2023. This estimate, however, is based on data from 1955 to 2014, which may have been a stable time for FDL-A. The recent enlargement of the upper RTS and the formation of large, persistent transverse cracks across FDL-A mirrors the pattern of instability demonstrated by FDL-D. These features may forecast rapid downslope movement for FDL-A.

While the results of the research presented here have increased our understanding of the composition, morphology, and movement trends of FDLs, this study is not without limitations. (1) Lack of aerial imagery limited the historic image analysis. Many data sets were unusable due to cloud cover, lighting conditions and shadowing, and damage to the film. Analysis of additional imagery could refine the rate trends, and identify the exact timing of rapid movement for FDL11, FDL-7, and FDL-D. (2) The organic material sampled 


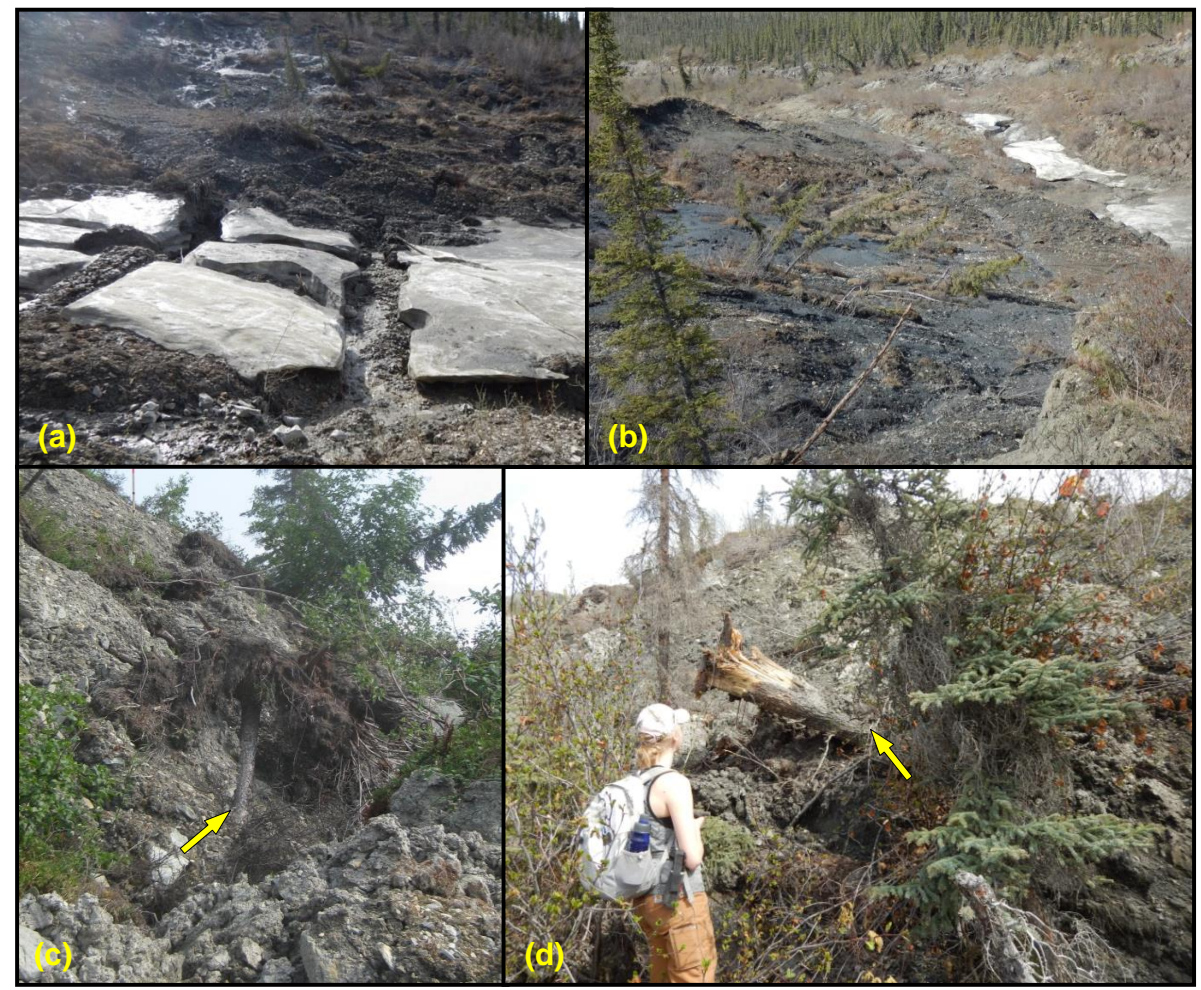

Figure 11. Destabilization of FDL-D. (a) Evidence of ongoing movement throughout the 2014-2015 winter and spring, as transverse cracks separate an aufeis deposit on the upper lobe. (b) View down the lobe from the head scarp of one of many RTSs in the catchment, looking over a debris flow originating from the exposed massive ice. (c) Tree completely upside down with root mass sticking out of a crack. (d) Trunk of tree sticking out of debris at toe of FDL-D. Yellow arrows in (c) and (d) point to the tree trunks exiting the lobe surface.

from FDL-A provided preliminary evidence for its initial downslope movement from the catchment. Additional samples should be collected on FDL-A and the other FDLs to increase the understanding of movement history. (3) The observations presented here indicate that FDL changes in movement may be tied to changes in air temperature. Unfortunately, long-term temperature data do not exist for the immediate area. Future studies could monopolize on the spruce forests in the area by developing a proxy climate record from tree-ring analysis. (4) From our observations, we suspect that infiltration ice comprises a considerable percentage of FDL volume; however, we cannot estimate this volume based on current data. We recommend the use of geophysical methods, specifically IPT, combined with additional drilling to determine better estimates of ice. (5) Finally, ongoing measurements of surface movement will provide more refined estimates of rates, allowing field identification of destabilization features.

\section{Conclusions}

We present the results of the first comprehensive study of eight FDLs near the Dalton Highway in the Brooks Range, which include repeated surface measurements, rock strength testing, soil engineering index property testing, isotope analysis of infiltration ice, radiocarbon dating, and analysis of historic images of the AOI. Analysis of these various data sets provided answers to initial questions.

1. The bedrock forming the majority of the catchments has very low to medium strength and is heavily fractured. These characteristics indicate that the bedrock responds quickly and easily to physical weathering processes, and thus contributes to the formation of FDLs.

2. FDLs consist of platy rocks typical of their catchments, along with organic debris, and an ice-poor soil matrix composed of silty sand with varying amounts of gravel. Massive ice is present within FDLs as infiltration ice, concentrated within cracks open to the surface. Increased movement and exposure of ice in RTSs leads to various stages of destabilization, resulting in morphologic differences among the lobes.

3. Movement of the FDLs within the AOI has been asynchronous since 1955, with FDL-11 demonstrating significant movement in the 1970s followed by quiescence, while FDL-7, FDL-D, and FDL-5 currently demonstrate significant movement and/or increasing signs of destabilization. The radiocarbon dating results provide 
other preliminary evidence of asynchronous movement, indicating that FDL-A began to move out of its catchment over 700 years ago, demonstrating either greater or earlier downslope movement than any of the other FDLs.

4. Since 1955, six of the eight investigated lobes have demonstrated an increase in movement rates. The formation of surface features, such as cracks, scarps, and RTSs, suggests that the increased movement rates correlate to general instability.

5. We offer a formation scenario of the FDLs after deglaciation of the area, as well as observations on contributing factors to lobe movement and destabilization.

6. Even at a distance, FDLs are impacting infrastructure through increased sediment mobilization. Based on its current distance and rate of movement, we predict that FDL-A will reach the Dalton Highway alignment by 2023; however, this estimate does not account for the signs of increasing instability in the upper reaches of FDL-A.

\section{The Supplement related to this article is available online at doi:10.5194/tc-10-977-2016-supplement.}

Acknowledgements. This work was funded by grants from the US Department of Transportation (OASRTRS-14-H-UAFProject B), the Alaska Department of Transportation and Public Facilities (ADOT \& PF) (T2-12-17), and through generous support from the Alaska Division of Geological \& Geophysical Surveys' Capital Improvement Project and the Alyeska Pipeline Service Company. The authors thank L. Southerland for her help in the field and in the lab; L. Wirth and M. Slife for their expertise and guidance with the historic imagery; A. Emond and R. Fortier for their expertise in geophysics; Y. Shur, M. Kanevskiy, and S. Stuefer for their valuable input; and numerous colleagues from ADOT \& PF and Alyeska. We thank W. Haeberli and an anonymous reviewer for their valuable comments that helped to improve this manuscript.

Disclaimer. The views, opinions, findings, and conclusions reflected in this paper are the responsibility of the authors only and do not represent the official policy or position of the USDOT/OST$\mathrm{R}$, or any state agency or entity.

Edited by: K. Isaksen

\section{References}

AASHTO - American Association of State Highway and Transportation Officials: AASHTO Standard Specifications for Transportation Materials and Methods of Sampling and Testing (Part 2A - Tests), 29th Edn., AASHTO, Washington, D.C., T111, T27-1, T267-1, 2009.

Arenson, L., Colgan, W., and Marshall, H. P.: Physical, thermal and mechanical properties of snow, ice and permafrost, in: Snow and Ice-Related Hazards, Risks, and Disasters, edited by: Haeberli, W., Whiteman, C., and Shroder, J. F., Elsevier Science, Saint Louis, 35-75, 2015.

ASGDC - Alaska State Geo-Spatial Data Clearinghouse: Geospatial Data, http://www.asgdc.state.ak.us/ (last access: 9 December 2015), 2014.

ASPRS - American Society of Photogrammetry and Remote Sensing: New standard for new era: overview of the 2015 ASPRS positional accuracy standards for digital geospatial data, http://www.asprs.org/a/society/committees/standards/ PERS_March2015_Highlight.pdf (last access: 27 January 2016), 2015.

ASTM: D2216 Standard Test Methods for Laboratory Determination of Water (Moisture) Content of Soil and Rock by Mass, ASTM International, West Conshohocken, 1990.

ASTM: D422 Standard Test Method for Particle-Size Analysis of Soils, ASTM International, West Conshohocken, 1998.

ASTM: D4318 Standard Test Method for Liquid Limit, Plastic Limit, and Plasticity Index of Soils, ASTM International, West Conshohocken, 2000.

Ballantyne, C. K., Schnabel, C., and Xu, S.: Exposure dating and reinterpretation of coarse debris accumulation ('rock glaciers') in the Cairngorm Mountains, Scotland, J. Quaternary Sci., 24, 19-31, 2009.

Barsch, D.: Nature and importance of mass-wasting by rock glaciers in alpine permafrost environments, Earth Surf. Proc., 2, 231-245, 1977.

Berthling, I., Etzelmüller, B., Eiken, T., and Sollid, J. L.: The rock glaciers on Prins Karls Forland: corrections of surface displacement rates, Permafrost Periglac. Process., 14, 291-293, 2003.

Blumstengel, W. and Harris, S. A.: Observations on an active lobate rock glacier, Slims River Valley, St. Elias Range, Canada, Permafrost, 5th International Conference on Permafrost, 2-5 August 1988, Tronheim, Norway, 689-694, 1988.

Bollman, E., Girstmair, A., Mitterer, S., Krainer, K., Sailer, R., and Stötter, J.: A rock glacier activity index based on rock glacier thickness changes and displacement rates derived from airborne laser scanning, Permafrost Periglac. Process., 26, 347-359, 2015.

Brenning, A. and Azocar, G. F.: Statistical analysis of topographic and climatic controls and multispectral signatures of rock glaciers in the Dry Andes, Chile $\left(27^{\circ}-33^{\circ} \mathrm{S}\right)$, Permafrost Periglac. Process., 21, 54-66, 2010.

Brown, J. and Kreig, R. A.: Guidebook to Permafrost and Related Features along the Elliott and Dalton Highways, Fox to Prudhoe Bay, Alaska, Alaska Division of Geological \& Geophysical Surveys Guidebook, Fairbanks, 145-149, 1983.

Burn, C. R.: The thermal regime of a retrogressive thaw slump near Mayo, Yukon Territory, Can. J. Earth Sci., 37, 967-981, 2000.

Calkin, P. E., Haworth, L. A., and Ellis, C. J.: Rock glacier of Central Brooks Range, Alaska, U.S.A., Rock Glaciers, edited by: Gi- 
ardino, J. R., Shroder, J. F., and Vitek, J. D., Allen and Unwin, Boston, 65-82, 1987.

Calkin, P. E., Kaufman, D. S., Przybyl, B. J., Whitford, W. B., and Peck, B. J.: Glacier regimes, periglacial landforms, and Holocene climate change in the Kigluaik Mountains, Seward Peninsula, Alaska, USA, Arct. Alp. Res., 30, 154-165, 1998.

Christiansen, H. H., Etzelmüller, B., Isaksen, K., Juliussen, H., Farbrot, H., Humlum, O., Johansson, M., Ingeman-Nielsen, T., Kristensen, L., Hjort, J., Holmlund, P., Sannel, A. B. K., Sigsgaard, C., Åkerman, H. J., Foged, N., Blikra, L. H., Pernosky, M. A., and Ødegård, R. S.: The thermal state of permafrost in the Nordic area during the international polar year 2007-2009, Permafrost Periglac. Process., 21, 156-181, 2010.

Cornforth, D. H.: Landslides in Practice: Investigations, Analysis, and Remedial/Preventative Options in Soils. John Wiley \& Sons, Inc., Hoboken, p. 176, 2005.

Daanen, R. P., Grosse, G., Darrow, M. M., Hamilton, T. D., and Jones, B. M.: Rapid movement of frozen debris-lobes: implications for permafrost degradation and slope instability in the south-central Brooks Range, Alaska, Nat. Hazards Earth Syst. Sci., 12, 1521-1537, doi:10.5194/nhess-12-1521-2012, 2012.

Darrow, M. M., Daanen, R. P., and Simpson, J. M.: Monitoring and Analysis of Frozen Debris Lobes, Phase I: FHWA-RD-AK-12, INE/AUTC 12.25, UAF Institute of Northern Engineering, Fairbanks, 63 pp., 2012.

Darrow, M. M., Daanen, R. P., and Simpson, J. M.: Analysis of a frozen debris lobe: a first look inside an impending geohazard, 2-5 June 2013, ISCORD 2013, 139-148, 2013.

Darrow, M. M., Simpson, J. M., Daanen, R. P., and Hubbard, T.: Characterizing a frozen debris lobe, Dalton Highway, Alaska, 19-22 July 2015, Cold Regions Engineering 2015: Developing and Maintaining Resilient Infrastructure, 57-67, 2015.

Davis, N.: Permafrost: A Guide to Frozen Ground in Transition, University of Alaska Press, Fairbanks, 95-97, 160-164, 2001.

Deline, P., Gruber, S., Delaloye, R., Fischer, L., Geertsema, M., Giardino, M., Hasler, A., Kirkbride, M., Krautblatter, M., Magnin, F., McColl, S., Ravanel, L., and Schoeneich, P.: Ice loss and slope stability in high-mountain regions, in: Snow and Ice-Related Hazards, Risks, and Disasters, edited by: Haeberli, W., Whiteman, C., and Shroder, J. F., Elsevier Science, Saint Louis, 521561,2015

Dillon, J. T., Harris, A. G., Dutro, Jr., J. T., Solie, D. N., Blum, J. D., Jones, D. L., and Howell, D. G.: Preliminary Geologic Map and Section of the Chandalar D-6 and Parts of the Chandalar C-6 and Wiseman C-1 and D-1 Quadrangles, Alaska, Alaska Division of Geological \& Geophysical Surveys Report of Investigation 88-5, 1 sheet, scale 1:63 360, Alaska Division of Geological \& Geophysical Surveys, Fairbanks, Alaska, 1988.

Douglas, T. A., Fortier, D., Shur, Y. L., Kanevskiy, M. Z., Guo, L., Cai, Y., and Bray, M. T.: Biogeochemical and geocryological characteristics of wedge and thermokarst-cave ice in the CRREL permafrost tunnel, Alaska, Permafrost Periglac. Process., 22, 120-128, 2011.

Ellis, J. M. and Calkin, P. E.: Chronology of Holocene glaciation, central Brooks Range, Alaska, Geol. Soc. Am. Bull., 95, 897912, 1984

Embleton, C. and King, C. A. M.: Periglacial Geomorphology, John Wiley \& Sons, New York, p. 203, 1975.
EOP - Executive Office of the President: Implementation Plan for the National Strategy for the Arctic Region, available at: http: //www.whitehouse.gov/sites/default/files/docs/implementation plan_for_the_national_strategy_for_the_arctic_region-fi.pdf (last access: 12 January 2015), 2014.

Farbrot, H., Etzelmüller, B., Guomundsson, A., Humlum, O., Kellerer-Pirklbauer, A., Eiken, T., and Wangensteen, B.: Rock glaciers and permafrost in Trollaskagi, northern Iceland, Z. Geomorphol., 51, 1-16, 2007.

French, H. M.: The Periglacial Environment, 3rd Edn., Wiley, Chichester, West Sussex, p. 458, 2007.

Geertsema, M., Clague, J. J., Schwab, J. W., and Evans, S. G.: An overview of recent large catastrophic landslides in northern British Columbia, Canada, Eng. Geol., 83, 120-143, 2006.

GINA - Geographic Information Network of Alaska: Interferometric Synthetic Aperture Radar (IfSAR), http://www.gina.alaska. edu/data/ifsar (last access: 9 December 2015), 2001.

Gooseff, M. N., Balser, A., Bowden, W. B., and Jones, J. B.: Effects of hillslope thermokarst in northern Alaska, EOS, 90, 2930, 2009.

Gorbunov, A. P. and Seversky, E. V.: Solifluction in the mountains of central Asia: distribution, morphology, processes, Permafrost Periglac. Process., 10, 81-89, 1999.

Gruber, S. and Haeberli, W.: Permafrost in steep bedrock slopes and its temperature-related destabilization following climate change, J. Geophys. Res.-Earth, 112, F02S18, doi:10.1029/2006JF000547, 2007.

Gude, M. and Barsch, D.: Assessment of geomorphic hazards in connection with permafrost occurrence in the Zugspitze area (Bavarian Alps, Germany), Geomorphology, 66, 85-93, 2005.

Haeberli, W. and Vonder Mühll, D.: On the characteristics and possible origins of ice in rock glacier permafrost, Z. Geomorphol., 104, 43-57, 1996.

Haeberli, W., Hallet, B., Arenson, L., Elconin, R., Humlum, O., Kääb, A., Kaufmann, V., Ladanyi, B., Matsuoka, N., Springman, S., and Mühll, D. V.: Permafrost creep and rock glacier dynamics, Permafrost Periglac. Process., 17, 189-214, 2006.

Haeberli, W., Hoelzle, M., Kääb, A., Keller, F., Vonder Mühll, D., and Wagner, S.: Ten years after drilling through the permafrost of the active rock glacier Murtèl, eastern Swiss Alps: answered questions and new perspectives, Permafrost - 7th International Conference (Proceedings), Yellowknife, Canada, Collection Nordicana, 55, 403-410, 1998.

Hamilton, T. D.: Surficial Geologic Map of the Chandalar Quadrangle, Alaska, US Geological Survey Miscellaneous Field Studies Map MF-878A, scale $1: 250$ 000, US Geological Survey, Reston, VA, 1978.

Hamilton, T. D.: Surficial Geologic Map of the Wiseman Quadrangle, Alaska. USGeological Survey Miscellaneous Field Studies Map MF-1122, scale 1 : 250 000, US Geological Survey, Reston, VA, 1979.

Hamilton, T. D.: Surficial Geologic Map of the Survey Pass Quadrangle, Alaska, US Geological Survey Miscellaneous Field Studies Map MF-1320, scale $1: 250$ 000, US Geological Survey, Reston, VA, 1981.

Hamilton, T. D.: Late Cenozoic Glaciation of the Central Brooks Range, in: Glaciation in Alaska: The Geologic Record, edited by: Hamilton, T. D., Reed, K. M., and Thorson, R. M., Alaska Geological Society, Anchorage, Alaska, 9-50, 1986. 
Harris, C., Kern-Luetschg, M., Muron, J., Font, M., Davies, M., and Smith, F.: Solifluction processes on permafrost and nonpermafrost slopes: results of a large-scale laboratory simulation, Permafrost Periglac. Process., 19, 359-379, 2008a.

Harris, C., Smith, J. S., Davies, M. C. R., and Rea, B.: An investigation of periglacial slope stability in relation to soil properties based on physical modelling in the geotechnical centrifuge, Geomorphology, 93, 437-459, 2008b.

Hauck, C.: New concepts in geophysical surveying and data interpretation for permafrost terrain, Permafrost Periglac. Process., 24, 131-137, 2013.

Hubbard, T. D., Koehler, R. D., and Combellick, R. A.: High-resolution lidar data for Alaska infrastructure corridors, Lidar Datasets of Alaska, Alaska Division of Geological \& Geophysical Surveys Raw Data File 2011-3, Alaska Division of Geological \& Geophysical Surveys, http://dggs.alaska. gov/pubs/id/22722 (last access: 15 June 2013), 2011.

Humlum, O.: The climatic significance of rock glaciers, Permafrost Periglac. Process., 9, 375-398, 1998a.

Humlum, O.: Rock glaciers on the Faeroe Islands, the north Atlantic, J. Quaternary Sci., 13, 293-307, 1998b.

Ikeda, A. and Matsuoka, N.: Pebbly versus bouldery rock glaciers: morphology, structure and processes, Geomorphology, 73, 279296, 2006

Ikeda, A., Matsuoka, N., and Kääb, A.: Fast deformation of perennially frozen debris in a warm rock glacier in the Swiss Alps: An effect of liquid water, J. Geophys. Res., 113, F01021, doi:10.1029/2007JF000859, 2008.

Isaksen, K., Ødegård, R. S., Eiken, T., and Sollid, J. L.: Composition, flow, and development of two tongue-shaped rock glaciers in the permafrost of Svalbard, Permafrost Periglac. Process., 11, 241-248, 2000.

Jorgenson, M. T., Yoshikawa, K., Kanevskiy, M., Shur, Y. L., Romanovsky, V. E., Marchenko, S., Grosse, G., Brown, J., and Jones, B.: Permafrost characteristics of Alaska, Extended Abstr., 9th International Conference on Permafrost, 28 June3 July 2008, Fairbanks, Alaska, 121-122, 2008.

Kääb, A., Haeberli, W., and Gudmundsson, G. H.: Analysing the creep of mountain permafrost using high precision aerial photogrammetry: 25 years of monitoring Gruben Rock Glacier, Swiss Alps, Permafrost Periglac. Process., 8, 409-426, 1997.

Kääb, A., Frauenfelder, R., and Roer, I.: On the response of rock glacier creep to surface temperature increase, Global Planet. Change, 56, 172-187, 2007.

Kehew, A. E.: Geology for Engineers and Environmental Scientists, 3rd Edn., Pearson Prentice Hall, New Jersey, 214-250, 2006.

Kokelj, S. V., Lantz, T. C., Kanigan, J., Smith, S. L., and Coutts, R.: Origin and polycyclic behaviour of tundra thaw slumps, Mackenzie Delta region, Northwest Territories, Canada, Permafrost Periglac. Process., 20, 173-184, 2009.

Krainer, K., Bressan, D., Dietre, B., Haas, J. N., Hajdas, I., Lang, K., Mair, V., Nickus, U., Reidl, D., Thies, H., and Tonidandel, D.: A 10,300-year-old permafrost core from the active rock glacier Lazaun, southern Ötztal Alps (South Tyrol, northern Italy), Quaternary Res., 83, 324-335, 2015.

Kreig, R. A. and Reger, R. D.: Air-photo Analysis and Summary of Landform Soil Properties along the Route of the Trans-Alaska Pipeline System, Alaska Division of Geological \& Geophysical Surveys, Anchorage, 74-75, 1982.
Lewkowicz, A. G. and Harris, C.: Morphology and geotechnique of active-layer detachment failures in discontinuous and continuous permafrost, northern Canada, Geomorphology, 69, 275-297, 2005.

Malone, L., Lacelle, D., Kokelj, S., and Clark, I. D.: Impacts of hill slope thaw slumps on the geochemistry of permafrost catchments (Stony Creek watershed, NWT, Canada), Chem. Geol., 356, 3849, 2013.

Matsuoka, N., Ikeda, A., and Date, T.: Morphometric analysis of solifluction lobes and rock glaciers in the Swiss Alps, Permafrost Periglac. Process., 16, 99-113, 2005.

Meyer, H., Dereviagin, A., Siegert, C., Schirrmeister, L., and Hubberten, H.-W.: Paleoclimate reconstruction on Big Lyakhovsky Island, North Siberia - hydrogen and oxygen isotopes in ice wedges, Permafrost Periglac. Process., 13, 91-105, 2002.

Meyer, H., Schirrmeister, L., Andreev, A., Wagner, D., Hubberten, H.-W., Yoshikawa, K., Brobrov, A., Wetterich, S., Opel, T., Kandiano, E., and Brown, J.: Lateglacial and Holocene isotopic and environmental history of northern coastal Alaska - results from a buried ice-wedge system at Barrow, Quaternary Sci. Rev., 29, 37200-3735, 2010.

Micheletti, N., Lambiel, C., and Lane, S. N.: Investigating decadal-scale geomorphic dynamics in an alpine mountain setting, J. Geophys. Res.-Earth, 120, 2155-2175, doi:10.1002/2015JF003656, 2015.

Milligan, G., Fookes, P. G., and Lee, E. M. (Eds.): Engineering behaviour of soils and rocks, in: Geomorphology for Engineers, CRC Press, Boca Raton, 137-169, 2005.

Reimer, P. J., Bard, E., Bayliss, A., Beck, J. W., Blackwell, P. G., Ramsey, C. B., Buck, C. E., Cheng, H., Edwards, R. L., Friedrich, M., Grootes, P. M., Guiderson, T. P., Haflidason, H., Hajdas, I., Hatté, C., Heaton, T. J., Hoffman, D. L., Hogg, A. G., Hughen, K. A., Kaiser, K. F., Kromer, B., Manning, S. W., Niu, M., Reimer, R. W., Richards, D. A., Scott, E. M., Southon, J. R., Staff, R. A., Turney, C. S. M., and van der Plicht, J.: INTCAL13 and MARINE13 radiocarbon age calibration curves 050,000 years cal BP, Radiocarbon, 55, 1869-1887, 2013.

Romanovsky, V. E., Smith, S. L., and Christiansen, H. H.: Permafrost thermal state in the polar northern hemisphere during the International Polar Year 2007-2009: a synthesis, Permafrost Periglac. Process., 21, 106-116, 2010.

Sevunts, L.: Canada and Russia stress Arctic economic development, CBC News, available at: http://www.cbc.ca/news/canada/north/ canada-and-russia-stress-arctic-economic-development-1. 1407697 (last access: 12 January 2015), 2013.

Simpson, J. M., Darrow, M. M., Huang, S. L., Daanen, R. P., and Hubbard, T. D.: Investigating movement and characteristics of a frozen debris lobe, South-Central Brooks Range, Alaska, Environ. Eng. Geosci., doi:10.2113/EEG-1728, in press, 2016.

Smith, S. L., Romanovsky, V. E., Lewkowicz, A. G., Burn, C. R., Allard, M., Clow, G. D., Yoshikawa, K., and Throop, J.: Thermal state of permafrost in North America: a contribution to the International Polar Year, Permafrost Periglac. Process., 21, 117-135, 2010.

Sorg, A., Kääb, A., Roesch, A., Bigler, C., and Stoffel, M.: Contrasting responses of Central Asian rock glaciers to global warming, Scient. Rep., 5, 8228, doi:10.1038/srep08228, 2015. 
Spangler, E. R. and Hubbard, T. D.: Geologic and geomorphic characterization of frozen debris lobe source basins along the Dalton Highway, southern Brooks Range, Alaska, Alaska Division of Geological \& Geophysical Surveys, Fairbanks, 34 pp., in review, 2016.

Spangler, E. R., Hubbard, T. D., Daanen, R. P., Darrow, M. M., Simpson, J. M., and Southerland, L. E.: Geologic and geomorphic characterization of frozen debris lobe catchments along the Dalton Highway, southern Brooks Range, Alaska (poster), GSA Annual Meeting, Abstracts with Programs (49-16), 45, 152, 2013.

Stocker, T. F., Qin, D., Plattner, G.-K., Tignor, M. M. B., Allen, S. K., Boschung, J., Nauels, A., Xia, Y., Bex, V., and Midgley, P. W. (Eds.): Climate Change 2013: The Physical Science Basis, in: Working Group I Contribution to the Fifth Assessment Report of the Intergovernmental Panel on Climate Change, Cambridge University Press, Cambridge, 121-122, 2013.

Swanger, K. M. and Marchant, D. R.: Sensitivity of ice-cemented Antarctic soils to greenhouse-induced thawing: are terrestrial archives at risk?, Earth Planet. Sc. Lett., 259, 347-359, 2007.
Tarussov, A.: The Arctic from Svalbard to Severnaya Zemlya: climatic reconstructions from ice cores, in: Climate Since A.D. 1500, edited by: Bradley, R. S. and Jones, P. D., Routledge, London, 505-516, 1992.

Wahrhaftig, C.: Physiographic Divisions of Alaska, USGS Professional Paper 482, USGS, Washington, D.C., 20-22, 1965.

Wahrhaftig, C. and Cox, A.: Rock glaciers in the Alaska Range, Geol. Soc. Am. Bull., 70, 383-436, 1959.

Washburn, A. L.: Periglacial problems, in: Field and Theory: Lectures in Geocryology, edited by: Church, M. and Slaymaker, O., University of British Columbia Press, Vancouver, 166-202, 1985.

Williams, P. J. and Smith, M. W.: The Frozen Earth: Fundamentals of Geocryology, Cambridge University Press, Cambridge, 2737, 1989.

Wirz, V., Gruber, S., Purves, R. S., Beutel, J., Gärtner-Roer, I., Gubler, S., and Vieli, A.: Short-term velocity variations at three rock glaciers and their relationship with meteorological conditions, Earth Surf. Dynam., 4, 103-123, doi:10.5194/esurf-4-1032016, 2016. 